Fall 1994

\title{
Choosing Palliative Care: Do Religious Beliefs Make a Difference?
}

M. Therese Lysaught

Loyola University Chicago, mlysaught@luc.edu

Follow this and additional works at: https://ecommons.luc.edu/ips_facpubs

Part of the Ethics in Religion Commons

\section{Recommended Citation}

M. Therese Lysaught. "Choosing Palliative Care: Do Religious Beliefs Make a Difference." Journal of Palliative Care 10 (Autumn 1994): 61-66, co-authored with Ron P. Hamel, Ph.D.

This Article is brought to you for free and open access by the Faculty Publications and Other Works by Department at Loyola eCommons. It has been accepted for inclusion in Institute of Pastoral Studies: Faculty Publications and Other Works by an authorized administrator of Loyola eCommons. For more information, please contact ecommons@luc.edu.

\section{c) (†) $\ominus$}

This work is licensed under a Creative Commons Attribution-Noncommercial-No Derivative Works 3.0 License. (c) Journal of Palliative Care, 1994. 


\section{Choosing Palliative Care: Do Religious Beliefs Make a Difference?}

RONALD P. HAMEL and M. THERESE LYSAUGHT, The Park Ridge Center, Chicago, Illinois, USA

\section{INTRODUCTION}

Religious beliefs play a role for many individuals, explicitly and implicitly, positively and negatively, in decisions about whether or not to pursue palliative care. They also play a role in its practice. We review four ways in which religious beliefs can and do influence end-of-life decisions: (a) helping to shape individuals' worldviews, (b) giving form to their particular beliefs, (c) giving rise to moral principles and rules, and (d) shaping community character and dispositions. Recognition and understanding of the impact of religious beliefs on palliative care may be crucial in working with individual patients and their families, as well as in educating various audiences about palliative care. An illustration follows:

David, a 37-year-old gay man, is in the last stages of a three-year battle with AIDS. He has survived six hospitalizations, each one leaving him more debilitated. Now he is but a shadow of his former self - pale, emaciated, lethargic, mildly demented, and almost breathless. Aggressive medical treatment has reached its limits, and David's primary physician recommends to him, his companion, and his family that they consider palliative care.

David comes from a religious family. He himself has been religious throughout his life, despite the anxiety and pain caused him by his religious community's attitudes toward homosexuality. Now he and his family must decide whether to continue trying to prolong his life or to shift their energies toward improving the quality of his remaining life. In making this decision, and the myriad of decisions associated with it, what impact might their religious beliefs have? What difference might it make if David and his family are Orthodox Jews, or Methodists, or Roman Catholics, or Muslims, or Hindus?

Undoubtedly, a variety of reasons persuade terminally ill patients and their families to choose palliative care. For some, choosing palliative care may be a way of asserting their autonomy against the threat of a technologized death. For others, palliative care promises to better meet the needs of the terminally ill, allowing them to die at home in the company of family for example, and to address their fears by offering holistic care. For still others, a palliative approach to the end of life fits best with the religious traditions which have informed their lives.

In this article, we focus on the ways in which religious traditions can provide complementary or alternative frameworks for considering a palliative approach to the end of life. Palliative care consists largely in forgoing all technological interventions except those necessary to provide comfort and in addressing physical, psychological, social, and spiritual symptoms and needs. Thus religiously based attitudes toward the withdrawing and withholding of treatment, or the use of drugs, or the management of pain may be significant in facilitating or hindering an openness to palliative care. Equally significant may be the religiously oriented patient's beliefs about the value of life, the scope of human responsibility for life, and the meaning of suffering and death.

In the following pages, we offer a topology of the interactions between religious beliefs and palliative care decisions, drawing upon various religious traditions as illustrations in a broad sweeping way. Despite this too cursory overview, we hope to underscore not only the role which religious beliefs can and do play in endof-life decisions but also the importance of taking such beliefs into account in dealing with individual patients and their families and in educating various audiences about palliative care.

\section{RELIGIOUS TRADITIONS AND PALLIATIVE CARE DECISIONS: A TOPOLOGY}

Religious traditions can inform particular decisions in at least four different ways: by shaping worldview, particular beliefs, moral principles and rules, and character and community formation. Clearly, these levels are interrelated, often operate in tandem, and mutually influence each other. But it is helpful to separate them concep- 
tually to understand how each contributes to decisions regarding palliative care.

\section{Shaping Worldview}

Human beings are never human beings in general. They are always situated. Their common humanity is particularized by their belonging to a specific family, community, culture, ethnic group, race, social class, occupation, political party, and, for many, religious community. Each of these particular loci shapes individuals' identities and constitutes a part of the prism through which they view and interpret themselves and the world, especially their own lives and experiences.

While the role each particularization plays in an individual life varies, for many, involvement with religious communities proves especially significant; for example, being a Conservative Jew might be more determinative of personal identity and perspective on the world than being CEO of a major corporation. Religious traditions can be especially integral to the process of interpreting identity, existence, and experience because they are by nature sources of meaning. By fostering an overarching vision of reality, they provide insight into ultimate questions (e.g. the meaning of human existence and human history, the existence of some ultimate reality, the possibility of an afterlife) and basic human experiences (e.g. finitude, illness, suffering, and death).

Terminally ill patients obviously struggle with these kinds of issues. Many, knowingly or not, turn to their religious heritage for assistance in making sense of the meaning and purpose of their lives in light of the crises they face and subsequently in making decisions about how they will die. For example, the choice to cease trying to cure or to prolong life and instead improve the quality of what remains might be significantly shaped by an individual's response to the "ultimate question" of the afterlife (whether it exists, in what it consists, how it is related to the living of one's life).

Virtually all religious traditions see death as a passage bridging two segments of a continuous life $(1,2)$. Provided one has led a good and faithful earthly life, death is a transition to a better state of existence. In Christianity and Islam, afterlife is a qualitatively different state of existence, either a state where one comes "face to face" with God, characterized by peace, freedom from pain and suffering, and wholeness, or a state of eternal punishment. Christian traditions maintain that one's eternal destiny is decided in part by the kind of life one has led, although they generally hold that God's grace is more determinative. Relatedly, even though the
Qur'an emphasizes God's unlimited forgiveness and mercy, in the Islamic tradition the cumulative "weight" of an individual's deeds are of central importance to one's destiny (3). Thus, individuals who understand God primarily as a just judge rather than as a merciful redeemer may fear the nature of their eternal destiny and, consequently, be reluctant to face their deaths. Therefore, in David's case, because he has been told that he has lived a sinful life, he might fight death as long as possible. Equally, though, traditions with formal or sanctioned practices of forgiveness may help create a sense of communion with, rather than alienation from, God, thus enhancing the willingness to embark on the journey.

For Buddhists and Hindus, all creation is an expression of and embedded in an ongoing cycle of suffering and rebirth for which death is not the end. The afterlife is an integral part of their self-understanding and view of the world $(2,4,5)$. For certain individuals, usually those in monastic orders, death offers the way to the supreme goal of human existence, namely the soul's liberation from the cycle of rebirth (nirvana). Others anticipate the potential for being born into an improved state of human existence in one's next incarnation, although one's deeds in this life can likewise effect a negative outcome. Transcendent reality is nonpersonal, exhibiting neither mercy nor judgement; it does not intervene to change the course of an individual's fate. Thus, how particular Buddhists or Hindus assess the cumulative merit of their life's deeds (their karma) greatly influences their openness to dying.

Since almost all religious communities subscribe to some notion of afterlife, one would expect religious traditions to foster, even if only indirectly, an acceptance of death, i.e. a willingness to let go, to move on to the next phase of one's existence. Some believers adopt this orientation, but others may find their hope for an afterlife (and consequently their acceptance of death) diminished by a fear of non-existence or of what awaits them in the next life. In either case, the patient's global orientation informed by their religious formation may exert a very strong influence.

\section{Shaping Particular Beliefs}

Religious worldviews are comprised not only of convictions about ultimate questions but also of more specific beliefs regarding aspects of life, for example, beliefs about the value of human life, the worth of human beings, what constitutes a good quality of life, the extent of human dominion over life and nature, the nature of human 
freedom, the meaning of health, the goals of medicine, the place of technology, one's relationship to others, how God operates in the world. As with worldviews, what patients, families, and caregivers believe about these matters may likewise affect their overall approach to terminal illness in its various phases and to actual decisions about appropriate care.

Beliefs about the value of human life and the interaction of human and divine agency may strongly influence openness to palliative care. Most Christian traditions view life as a fundamental good, but not as an absolute one (6). It is considered sacred, a gift of the Creator entrusted to human care. It is a gift held in trust, to be returned to God throughout the course of life through worship, procreation, a good life, and finally death. Between birth and death, human beings have the responsibility to protect and preserve life; it is not theirs to do with what they want. But just as life is not absolute, neither is the Christian obligation to preserve it. Thus, were David to adopt this approach, he would likely feel morally clear to accept palliative care.

Some Christian communities, because they tend to place greater emphasis on the sacredness of life itself and on the limited autonomy of the person, are more restrictive about those circumstances in which it is morally permissible to forgo treatment. A few even require that biological life always be preserved, regardless of its quality or prospects for its duration. Some (e.g. certain conservative Evangelicals and Catholics) do so because they view life, physical life, as virtually absolute, if not absolute. Others (e.g. some Pentecostals) do so because of their view of God and God's relation to the world. The timing of the patient's death, they believe, is up to God and not to human caregivers. Or they believe that God will intervene in the dying process and restore the patient to some degree of health. Were David a member of one of these communities, he might feel that to agree to palliative care would be equivalent to lacking faith in God.

Within Judaism, the value attached to human life is even greater than in the Christian tradition (7). Here too life is viewed as a gift from God to be held in trust. Only God gives life and only God can take it away. But in Judaism, every moment of human life is considered of infinite value. And every human life is equally valuable. Every person is bound to save and protect not only his own life, but also that of fellow human beings. Even religious observances must be suspended in order to preserve life. Were, then, David an Orthodox Jew, he might feel obligated to pursue an aggressive course of treatment.
Beliefs about the place of pain and suffering in human life may likewise influence openness to forgoing aggressive treatment as well as decisions about pain management. All religious traditions have complex, and sometimes contradictory, understandings of pain and suffering. For all traditions, pain and suffering are one of the central characteristics of created reality. As the first of the Four Noble Truths of Buddhism states, suffering is the basic feature of existence. Although the aim of Buddhism is the cessation of suffering through the following of the Eightfold Path, enduring suffering this side of nirvana rather than fighting against it can be edifying. By bearing suffering well, one can cultivate good karma.

At the same time, insofar as the way prescribed by the Eightfold Path is an ideal of purity, peace, harmony, and happiness of heart and mind which is cultivated through right action and practices of meditation, a certain level of freedom from pain and satisfaction of bodily needs is required for the mind to be sufficiently free to meditate, be at peace, and be happy. But Buddhists also maintain that occupying the mind with meditation in the face of pain, suffering, and dying can cultivate peace and happiness, thereby contributing to one's karma. One's actions and state of mind during the process of dying can facilitate one's chances on the other side, but mental acuity is key: "The patient can have a happy death or a death that is a fearful struggle, depending on their tranquility and understanding. A happy death requires that the patient have a happy state of mind at the time of death. This in turn requires that the patient have full control over consciousness during the dying process" (5). Consequently, as a Buddhist, David might eschew aggressive pain management until the pain became so great that it compromised his mental status; then, however, he would likely prefer an analgesic regimen that would allow him to maintain clarity of consciousness as long as possible.

Christian traditions likewise have mixed understandings of pain and suffering. Suffering is understood as a fundamental characteristic of or flaw in created reality. Suffering may be construed as, at times, the result of personal actions, or trials sent by God to test an individual's faith, or as a gift of transformative and redemptive value. The dying Christian may feel called to witness to the presence and grace of God to others through their suffering or to join their sufferings with the sufferings of Christ for the redemption of the world. Christian traditions differ from the other monotheistic traditions in 
their belief that in the passion and death of Jesus Christ, God suffered. This has two consequences. First, God is believed to understand the agony of human suffering. Second, God continues to be present and suffer with those who suffer and is actually found precisely where there is suffering.

Most Christian traditions never enjoin that suffering be pursued as an end in itself, but neither is it something to be eliminated at all costs. Some more conservative Christian bodies emphasize the positive value of pain and suffering and encourage its acceptance. The majority, however, recognize the ways in which suffering can destroy not only the patient's identity and interpersonal relationships but also the patient's relationships with God, and thus they permit measures which alleviate pain and suffering. Mainline Christian traditions permit a sufficient use of analgesics to reduce pain even if doing so might hasten death by suppressing respiration. They also permit the treatment of anxiety and depression through the use of drugs. Most traditions would decide on the basis of benefits and risks to the patient.

Overall, most mainline religious traditions are readily open to and encourage adequate analgesic management of pain. Courses of treatment agreed to by individual patients may be shaped in part by their tradition's position and in part by the interpretation they give to the cause and meaning of their own suffering. It is important to note that in addition to sanctioning adequate pharmacological measures of pain control, most religious traditions, as we have seen above, are likewise open to alternative pain management techniques, such as prayer and meditation, music therapy, and so on.

\section{Shaping Moral Principles and Rules}

While religious beliefs may function generally, shaping a patient's overall orientation toward death and dying, religious traditions have also drawn implications from beliefs in the form of specific principles and guidelines for decision making as well as specific prescriptions and proscriptions. If a religious tradition maintains, for example, that human life is sacred and a gift of the Creator entrusted to human care, it may offer as a guiding moral principle "respect life" and as a moral rule "euthanasia is morally wrong" or "artificial nutrition and hydration must always be employed to sustain life."

With regard to specific principles and rules, two things must be kept in mind. First of all, many individuals do not fully understand their tradition's positions and may work with a less nuanced set of guidelines. On the other hand, not all members of a tradition adhere to official positions; the moral weight of such prescriptions and proscriptions varies within and among traditions depending on how members interpret their sacred writings, the authority they give to their religious leaders, and the emphasis they place on personal conscience.

Earlier we discussed the Jewish position on the sacredness of life and divine agency. Jewish authorities draw from these beliefs specific guidelines on forgoing treatment (8). Some maintain that physicians and others must make use of all available medical resources to prolong a patient's life, even if the patient lives for only a short time. In this perspective, withholding and surely withdrawing - life-sustaining treatment is forbidden and any action that hastened a patient's death, even if the patient requested it, would be an act of murder. Other authorities, however, maintain that not all measures must be employed if they solely prolong the dying process. Yet even here a distinction is made. Treatments which are natural or which are provided for treatable conditions unrelated to the terminal illness (e.g. oxygen, fluids and nutrition, antibiotics, and pain-relief medications) must be employed to the very end even against the patient's will. On the other hand, futile treatments directly related to the disease can and should be withheld (e.g. chemotherapy, dialysis, and resuscitation).

Likewise the Buddhist tradition draws implications for specific medical interventions from its beliefs about human existence and the afterlife. Formally, Buddhist traditions work with a whole-brain definition of death. As long as the brainstem shows activity, death has not yet occurred and the person still resides in the body; the consciousness "has not departed, but occupies an interior dimension. Even though comatose patients are helpless with regard to their physical body, the conscious mind, which has withdrawn within, may still be working to mentally prepare the patients for death. This process of mental cultivation can continue for as long as the patient has the 'life force' present in the body" (5). Consequently, caregivers need to support physical activities that support the activity of the brainstem: heartbeat, kidney dialysis, blood transfusion and nutrition.

\section{Shaping Community and Dispositions}

One of the primary purposes of all religious traditions is the formation of communities and the shaping of personal dispositions. Those individuals whose lives have been shaped by par- 
ticular religious communities may find it only reasonable that their dying process be likewise shaped. Alternatively, religious communities can often serve as latent resources that those who are estranged from the tradition may turn to in time of crisis to find the support and meaning they fail to find elsewhere.

Illness and dying can be particularly isolating, especially in contemporary culture where suffering and death are removed to the margins of society. To counter the reality and destructiveness of this isolation, all religious traditions contain strong injunctions for families and members of the community to visit and care for the sick and dying. Over the centuries, many traditions have developed formal, liturgical practices for such care (9). For Buddhists and Muslims, visiting and caring for the sick, and attending to, comforting, and relieving the suffering of others is a source of merit. Muslims are exhorted to visit the sick and give them hope and comfort; through self-giving to others the Muslim transcends the self, and for this God promises prosperity and forgiveness, in the next life if not in this. Christians are likewise exhorted to visit the sick and respond compassionately to a neighbor's suffering.

Consquently, should an individual belong to a supportive religious community that has wellestablished social and liturgical practices for attending to the sick and dying, he or she may be more inclined to accept a palliative approach to the end of life. These resources may likewise help families both by tending to their spiritual and social needs as well as by sharing the burden of care.

Through practices and beliefs, religious traditions seek not only to shape communities and common actions but also to inculcate in their members specific dispositions. For example, in the Buddhist traditions, practices of meditation are designed to mold peaceful and happy mental states and to instill the central moral virtue of Buddhism, compassion. Compassion is not understood so much as an emotion but rather as a stance toward the world in which one desires "to enhance the health of individual patients as well as to alleviate their suffering" simply because they are human and, therefore, vulnerable to pain and suffering.

Consequently, Buddhist health care practitioners, especially physicians, are expected to be toward the patient as a "good friend," charged with being the kind of person the patient can be at ease with, can trust, can understand, and can learn from the best way to die $(5,10)$. Compassion can likewise be practiced by the dying in their attitudes toward their caregivers and fam- ily members. In addition, compassion, combined with Buddhism's strong sense of social solidarity, might encourage particular Buddhists to voluntarily sacrifice their "right" to treatment in order to benefit others.

Christian traditions as well seek to shape dispositions that can positively affect care at the end of life. While often more preached than practiced, the Christian identity embraces a long tradition of actively welcoming those outcast by society - the stranger, the lame, the leper. Clearly, crossing boundaries of social class and taboo can be difficult. But Christians who, through and with their communities, participate in activities which intentionally foster such inclusion may find themselves disposed to care for those whom others reject. In David's case, his homosexuality may prove a barrier to many health care practitioners and members of religious communities that absolutely condemn homosexuality. Those whose dispositions are authentically formed by the Christian tradition would, however, be charged with welcoming and caring for David in his suffering.

Finally, all traditions affirm palliative care's attention to the dimension of spiritual care, especially as a palliative approach seeks to integrate the patient within a broad supportive community and foster transformative dispositions toward diminishment and death. We have noted the importance in the Buddhist tradition of the patient facing death peacefully, practicing meditation until the end. For Muslims, it is important to continue to participate in the practices of prayer and ablution, if possible, and to recite the confession of faith until the end. Some Christian traditions encourage practices of anointing the sick, praying with them, and sharing the eucharist with them. In many traditions, seeking forgiveness from God and/or making peace with others before death are important activities.

\section{CONCLUSION}

In summary, religious beliefs can and do affect palliative care decisions by forming the moral character of religiously oriented (and even some non-religiously and former religiously oriented) patients, family members, and caregivers. This character is expressed in the worldviews, beliefs, values, and dispositions that contribute to and lie beneath particular judgements and choices. They also shape specific principles and rules for moral guidance relevant to various aspects of palliative care.

On the whole, the beliefs of the major religious traditions, with the exception of some of the more conservative elements within these tra- 
ditions, are consistent with and even reinforce the goals and practice of palliative care. In principle they support (a) caring for all dimensions of the person, not just the physical; (b) forgoing treatment when cure is no longer possible and prolonging life is no longer reasonable; (c) alleviating pain even if that might lead to an earlier death; (d) recognizing the patient not as an isolated entity, but as part of a network of relationships which are integral to the patient's care; and (e) offering resources for addressing the spiritual needs of the terminally ill, particularly the need to give meaning to their lives, their suffering, and their dying.

In practice, however, religious beliefs do not always have a positive influence on end-of-life decisions and the pursuit of palliative care. Individuals may interpret them so as to (a) encourage or insist on the prolongation of life until the end; (b) consider the abatement of treatment, especially artificially administered nutrition and hydration, as killing; and (c) similarly judge the administration of analgesics that not only relieve pain but also shorten life. Patients or family members might also hold beliefs about the divine will (e.g. "She'll die when God wants her to"; "God gave life and only God should take it away") or divine intervention (e.g. "We're praying for a miracle") that could paralyze decisions about appropriate care. Or they might employ religious beliefs to foster attitudes which undermine efforts to meet the patient's psychological, social, and spiritual needs (e.g. "AIDS is God's judgement on his sinfulness"; "Homosexuals are condemned to hell"; "She hasn't been born again so she's not saved"). It may be particularly difficult when such religious beliefs create conflicts either between the patient and family members or between the caregivers and patients or patients' families.

Recognizing that religious beliefs can and do impact end-of-life decisions, even implicitly, and understanding the beliefs in question (whether the patient's, family's, or caregivers') can help to resolve potential or real difficulties and may in the end contribute to more appropriate patient care. This may be especially true for patients and families from cultural backgrounds different from that of the caregivers. In addition, at least for religiously oriented persons, receptiveness to palliative care might be enhanced if it is viewed as consistent with or even an expression of one's religious worldview and fundamental beliefs.

In the end it is important to recognize the fact that religious beliefs rarely stand alone but intertwine with other personal and cultural beliefs. Nor do they always function in a straightforward manner. Patients, families, and caregivers may need a particular belief or set of beliefs clarified. They may struggle to resolve particular, possibly contradictory, beliefs and emotions as they work through the process of facing dying. Consequently, health care practitioners need to work carefully with religious beliefs by seeking to integrate spirituality more thoroughly into medicine, holding ongoing conversations with patients and families, consulting with patients' clergy, and including religious issues in education about palliative care. These activities ought not be simply relegated to members of the pastoral care staff but should be participated in by all members of the health care team.

\section{REFERENCES}

1. Numbers RL, Amundsen DW (eds). Caring and Curing: Health and Medicine in the Western Religious Traditions. New York: Macmillan, 1986.

2. Sullivan LE (ed). Healing and Restoring: Health and Medicine in the World's Religious Traditions. New York: Macmillan, 1989.

3. Rahman F. Health and Medicine in the Islamic Tradition. New York: Crossroads, 1989.

4. Desai PN. Health and Medicine in the Hindu Tradition. New York: Crossroads, 1989.

5. Bhikkhu M. Buddhist ethics in the practice of medicine. In: Wei-hsun Fu C, Wawrytko, SA (eds). Buddhist Ethics and Modern Society. Westport, Connecticut: Greenwood Press, 1991; 210.

6. Catholic Health Association of the United States. Care of the Dying: A Catholic Perspective. St. Louis, Missouri: Catholic Health Association, 1993.

7. Feldman DM. Health and Medicine in the Jewish Tradition. New York: Crossroads, 1986.

8. Steinberg A. Jewish medical ethics. In: Lustig A (ed). Theological Developments in Bioethics: 1988-1990. Bioethics Yearbook, Vol. 1. Boston: Kluwer, 1991; 179-199.

9. Eschleman MJ. Death with Dignity: Significance of Religious Beliefs and Practices in Hinduism, Buddhism, and Islam. Today's O.R. Nurse 1992; 11: 19-22.

10. Ratanakul P. A Buddhist critique of principlism. In: DuBose ER, Hamel RP, O'Connell LO (eds). A Matter of Principles: Ferment in U.S. Bioethics. Philadelphia: Trinity Press International, 1994. 